\title{
Underwater Archaeological Heritage: A Media for Maritime Learning
}

\author{
Prabawa Dwi Putranto \\ Archaeology Department, Faculty of Humanities \\ Universitas Indonesia \\ Jakarta, Indonesia \\ stprabawa@yahoo.co.id
}

\begin{abstract}
Indonesian people evolved in the archipelago along the equator. Its strategic location and natural wealth of producing spices appeals foreigners to come. People in Nusantara are common with seafaring and thrive as a maritime nation. Cultural contact and a long history have left cultural heritage, most buried underground, and some sunk to the bottom of the sea. These cultural heritages contain information connected to the history and the culture of Indonesian people. Based on survey by the Directorate of Underwater Cultural Heritage in 2011, in Indonesia it is estimated that there are $\mathbf{3 8 0 7}$ underwater archeological sites. These sites must be preserved because it contains information about the past. Cultural heritage is very important as a part of learning as maritime nation, especially for the young generation. Indonesia is emphasizing in character building as a maritime nation, as mentioned by President Joko Widodo in his priority agenda called Nawa Cita. Publication and dissemination of information about the richness of Indonesian maritime culture is still rare. Therefore, this paper is aim to open our insight that there are an abundance of cultural heritage from our ancestors that needs to be guarded and understand together to reinforce our identity as a maritime nation.
\end{abstract}

\section{Keywords—cultural heritage; maritime; method of learning \\ I. INTRODUCTION}

Indonesia as a multicultural nation have undergone a cultural development since prehistoric until now. That culture evolved in every region and produce similarity and differences, which shows diversity.

Indonesian people evolved in the archipelago along the equator, between the Asian and Australian Continent, also Indian and Pacific Ocean. This archipelagic type of regions made Indonesia as a maritime nation.

Indonesia is multicultural because of different cultural root and ancestors' origin. Cultural contacts that occur for centuries eventually shape the nation character as a maritime nation.

Indonesian ancestors are basically Austronesian characterized with Mongoloid race. Originated from mainland China then migrated to Taiwan through the Philippines and the Malay Peninsula and into Indonesian Archipelago thousands of years ago. This migration by sea also shaped this maritime culture.
The strategic location of Nusantara and natural wealth of producing spices appeals foreigners to come since many centuries ago. Initially these foreigners are merchants, but some of them ruled Indonesia in economy and politics. Therefore, Indonesia had many foreign cultural influences such as Indian, Chinese, Islamic, and European.

During the century, when trade between the east and the west world begins to thrive through the Silk Road, people in the Archipelago are accustomed to the seafaring activity. These lead to the rise of central commerce in the coast of Sumatera, Java, and Kalimantan. Historical evidence stated that in the 2nd century Nusantara has had a trading connection with India. Furthermore in the 5th century it also formed a diplomatic connection with China. The emergence of maritime kingdom also reinforces evidence about the connection of Nusantara with foreign countries. Sriwijaya is one of the kingdoms that controlled trading in Malaka and Sunda Straits. In the next century is the emergence of Majapahit Kingdom. The growth of commerce increases at the time of Islamic Empire and the arrival of European nation (Sulistiyono, 2008, p. 42-43)

The cultural history as a maritime people thrived through the Independence Declaration of Indonesia at August 17th 1945. At this time the Archipelago region was united as one country Indonesia. Furthermore, Indonesian territory is declared in Juanda Declaration in December 13th 1957, which extended the sea area from three miles to 12 miles. This declaration is reinforced with the Indonesian Law Number 4 Year 1960 about Indonesian Waters. According to the Law, Indonesian territory is as follows:
1. Indonesian Territory
$: 5.193 .250 \mathrm{~km} 2$
a. Land area
b. Water area
2. Land and water ratio
3. Islands
4. Coastline length
: $2.027 .087 \mathrm{~km} 2$
: $3.166 .163 \mathrm{~km} 2$
$: 2: 3$
: 13.667 island
: 33.972 miles

In its development, there is a recalculation in 2002 and it is known that the Indonesian land area is $1.860 .359,67 \mathrm{~km} 2$ with 17.504 islands (Sutikno, 2008: 28-29). Other information from satellite photo which broadcast by Nederland Radio on February 19th 2003 and quoted by Singgih Tri Sulistiyono in his article (2008: 40), it is stated that Indonesian islands are 18.108 , much more than other sources.

Based on its territory, Indonesia has more water area than land. Cultural contact and a long history have left cultural 
heritage, most buried underground, and some sunk to the bottom of the sea. These cultural heritages contain information connected to the history and the culture of Indonesian people.

This history and culture of Indonesian people needs to be known by future generation and needs to be research more in depth. This paper points out that there are a lot of cultural heritage that needs to be preserved and understand together to strengthen our identity as a maritime nation.

\section{UnDERWATER ARCHAEOLOGICAL HERITAGE IN KARIMUNJAWA}

Indonesian long history had left many cultural heritages. Cultural heritage that we know of today is only a fragment of a whole cultural product of the past. Most of that cultural heritage is buried underground or sunk to the bottom of the sea. In the context of preservation, UNESCO has issued a regulation called The UNESCO Convention On the Protection of The Underwater Cultural Heritage. In the 1st article it is explained the definition of $\mathrm{UCH}$ as follows:

"Underwater cultural heritage" means all traces of human existence having a cultural, historical or archaeological character which have been partially or totally under water, periodically or continuously,

In Indonesia there is a Law that regulates the preservation of cultural heritage, which is the Law No 11 Year 2010 about Cultural Properties. According to the Law No 11 Year 2010 about Cultural Properties article 1 paragraph 1, cultural properties are "cultural heritage with material characteristic in the form of things, buildings, structures, sites, and region in land or water that needs to be preserve its existence because of its value to the history, knowledge, education, religion, and/or culture through the process of establishment.

A cultural heritage that has relevance with past lives can be enacted as a Cultural Property. Cultural property has significance value for science as well as the cultural history. A cultural heritage and its preservation awareness are very useful for the stabilization of ideology and to nourish national pride and to strengthen national identity awareness and enrich knowledge in general.

$\mathrm{UCH}$ in Indonesia are scattered through the Indonesian waters. According to the Directorate of Underwater Heritage in 2011, there are estimated about 3807 sites (2011). From that many site, there are location, which has concentrated sites, such as Bangka Belitung waters, Thousand Islands Archipelago, and Karimunjawa Archipelago.

This research is specifically in the Karimunjawa Archipelago. Karimunjawa Archipelago is located in Jepara District, Middle Java. In Karimunjawa water there are 10 underwater sites identified which consist of wood and iron ships. These sites are Geleang, Menyawaan, Kumbang, Parang, Indonor, Genteng, Seruni, Genting, Kapal Mati, and Pulau Nyamuk. In order to protect the natural resource, in 1988 Karimunjawa Archipelago established as a National Park.

Karimunjawa Archipelago is located northeast of Semarang

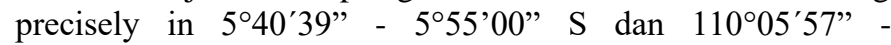
$110^{\circ} 31^{\prime} 15^{\prime \prime} \mathrm{E}$. It is located in the administrative region of District Jepara, consist of three village, Karimunjawa, Kemujan, and Parang. Its land and water area covers a 117.237 Ha, consist of 27 islands. There are only four inhabitant islands, which are Karimunjawa, Kemujan, Parang, and Nyamuk Island.

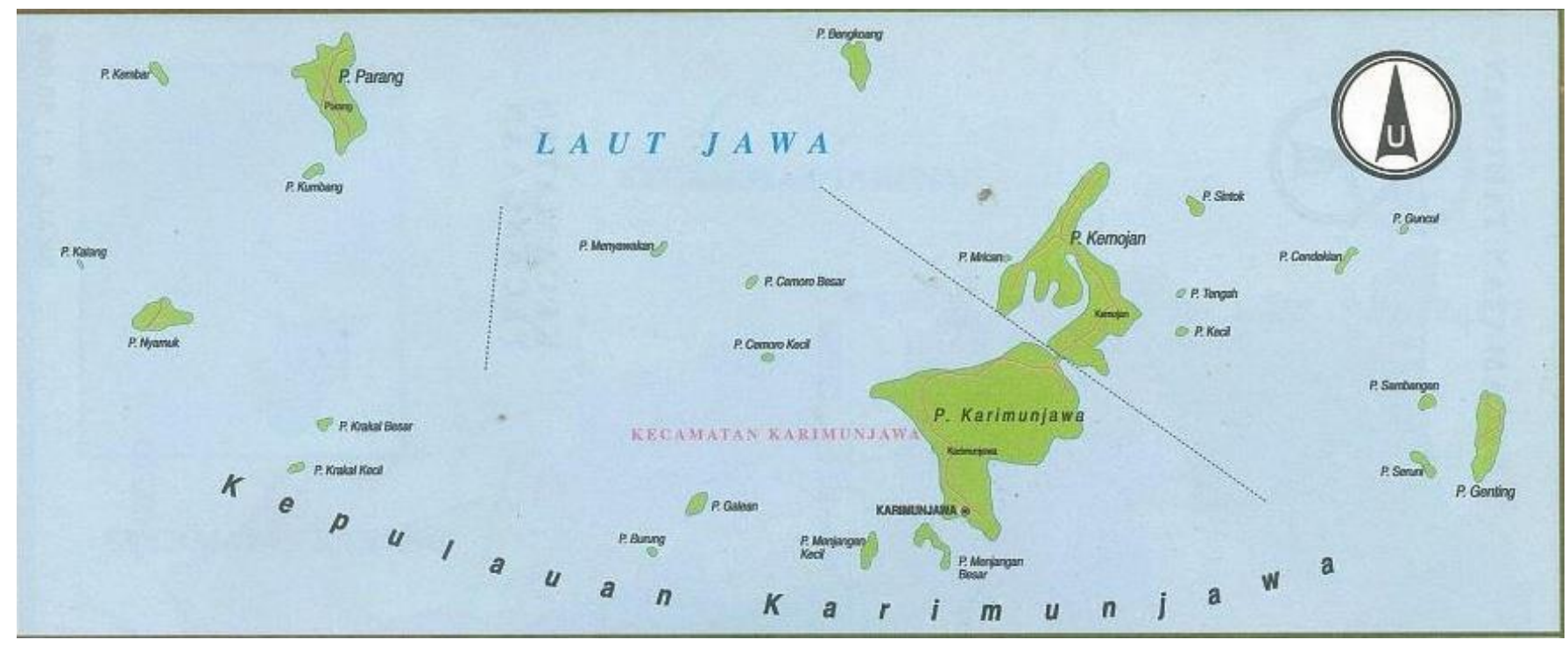

Fig. 1. Map of Karimunjawa Archipelago

Karimunjawa Archipelago location is very strategic to the shipping line and trade route of Java Sea. According to the Chinese chronicles, in the year 1292 A.D a 20.000 fleet envoy of Kubilai Khan led by Shih Pi, Kau Sing and Ike Mese sailed to Java to punish King Krtanegara (Singasari Kingdom). These fleet stop at Biliton (Belitung), and then anchored in Karimon 
(Karimunjawa), waiting for the opportunity to enter Du-bingzu (Tuban) (Groeneveldt, 2009: 32). In other Chinese Chronicles, Shun Feng Hsiang Sung who made the shipping route between China and Indonesian Archipelago, Chi Li Wen or Karimunjawa is depicted as an important place to the shipping between Wu Yu near Amoy (China) and Tu Ping Shu (Tuban) (Noerwidi, 2008, p. 5).

In the times of Demak Sultanate, when the main harbor shifted from Tuban to Jepara, Karimunjawa was still considered as a strategic location for transit in the Java Sea. Political control of Karimunjawa was managed by the Islamic Sultanate by sending mubaliq to convert the people to Islam. Among these notable figures are Sunan Nyamplung or Mbah Amir Khasan (Koestoro, 1997, p. 41-43).

In the 17th century, Jepara's role as the main harbor was replaced by Semarang. Although the main harbor changes again, Karimunjawa was still considered as an important transit harbor. According to Dutch record, in 18th and 19th Century furniture craftsmen in Batavia bring in its sonokeling wood (Indonesian rosewood) from Karimunjawa. In the year 1815, Carel Rudolph von Michalovski, a Germany officer appointed as the first posthouder to govern Karimunjawa.

In 1818 the Dutch Colonial recorded as much as 1.100 pirates exiled to Karimunjawa. Even some of them stayed on the island (Berg, 1992: 24-46). In the half of the 19th Century, the Semarang Residen built a governmental system in Karimunjawa to control their activity. In doing so, it lifted the status of Karimunjawa to a village, although in it was some islands such as Parang, Nyamuk, Kemujan and Genting (Gonggrijp, 1915:309). At the time of the Dutch Indies, Karimunjawa is administratively under the Resident of Semarang (Anwar, 2004, p. 188-189).

In the course of history, there are numerous cultural heritages in Karimunjawa, both in land and sea. There are 10 UCH sites in Karimunjawa, among other:

\section{1) Geleang site}

This site is located southwest of Geleang Island, a wooden ship in $48 \mathrm{~m}$ deep. Its condition in 70 percent, but there are still big ropes bound to the capstan. It size at $48 \mathrm{~m}$ long, 14.17 width, and $6 \mathrm{~m}$ high.

2) Menyawakan Site

This site is located near Menyawakan sandbar, $1 \mathrm{~km}$ from the coastline, an iron ship in 3-9 m deep. It is partially intact and buried in coral reef, but still identifiable its stern, bottom deck, hold, boiler, framework, steering wheel, main deck, and hatch. It size at $47 \mathrm{~m}$ long, 22 width, and $7 \mathrm{~m}$ high.

3) Kumbang Site

This site is located south of Kumbang Island, an iron ship in 2-13 m deep. Most of it is covered in coral, but 80 percent are still intact, such as the bridge, hold, stern, hatch, stair to the main deck, and a four windowed main deck. Based upon its hold layout, it is estimated as a cargo or a sand carrier. It size at $29 \mathrm{~m}$ long, 5.8 width, and $5 \mathrm{~m}$ high.

\section{4) Parang Site}

This site is located west of Parang Island, a wooden ship in 34-38 m deep. It is only 20 percent, most of the wood stolen by fisherman. There is still a stern $34 \mathrm{~m}$, portside, keel and framework, barrel and hoses. According to fisherman, the ship is Palipur Ship, a motorized sailing ship carrying building material. It size at $23 \mathrm{~m}$ long, 16 width, and $12 \mathrm{~m}$ high. Based on the age of coral reef by the National Park, it is estimated that the ship sunk in 2000-2005 (Karimunjawa National Park, 2010).

\section{5) Indonor Site}

This site is west of Karimunjawa Island. The site is S.S Indonor, an iron ship in 15 deep. It size at $99.94 \mathrm{~m}$ long, 14.17 $\mathrm{m}$ width, and $6 \mathrm{~m}$ high. According to history, S.S Indonor was made by a ship manufacturing company called William Gray \& Co. Ltd in the year 1941-1944. By the time of its manufacture, the ship was called Empire Pilgrim. S.S Indonor was a cargo ship "Scandinavian" type. It ended its journey on the way from Palembang to Surabaya on Wednesday, February 3th 1960, with its cargo of coal (Central Java Office Preservation of Cultural Heritage, 2011).

6) Genteng Site

This site is west of Little Menjangan Island. The site is Masa Indah, a motorized sailing ship in 29-30 m deep. It size at $21.97 \mathrm{~m}$ long, $7.69 \mathrm{~m}$ width. A wooden ship sunk on its way from Madura to Kalimantan carrying food, clothing and building materials

7) Seruni Site

This site is east of Seruni Island, $300 \mathrm{~m}$ from the coastline. It consists of fragments of wood from a ship in $10 \mathrm{~m}$ deep. It special features is a double construction of a ship.

\section{8) Genting Site}

This site is west of Genting Island, $500 \mathrm{~m}$ of the coastline. It consists of fragments os Chinese ceramics in $2 \mathrm{~m}$ deep. It is estimated from ancient Chinese dynasty.

\section{9) Dead Ship Site}

This site is southeast of Karimunjawa Island, $3 \mathrm{~km}$ from the coastline and $53 \mathrm{~m}$ deep. It was found only through a GPS Map Sounder. According to local source, the ship is made of wood.

10) Pulau Nyamuk Site

This site is west of Nyamuk Island, $200 \mathrm{~m}$ of the coastline and 3-4 m deep. On this site was found a 1 x $1 \mathrm{~m}$ of iron ship remains. 


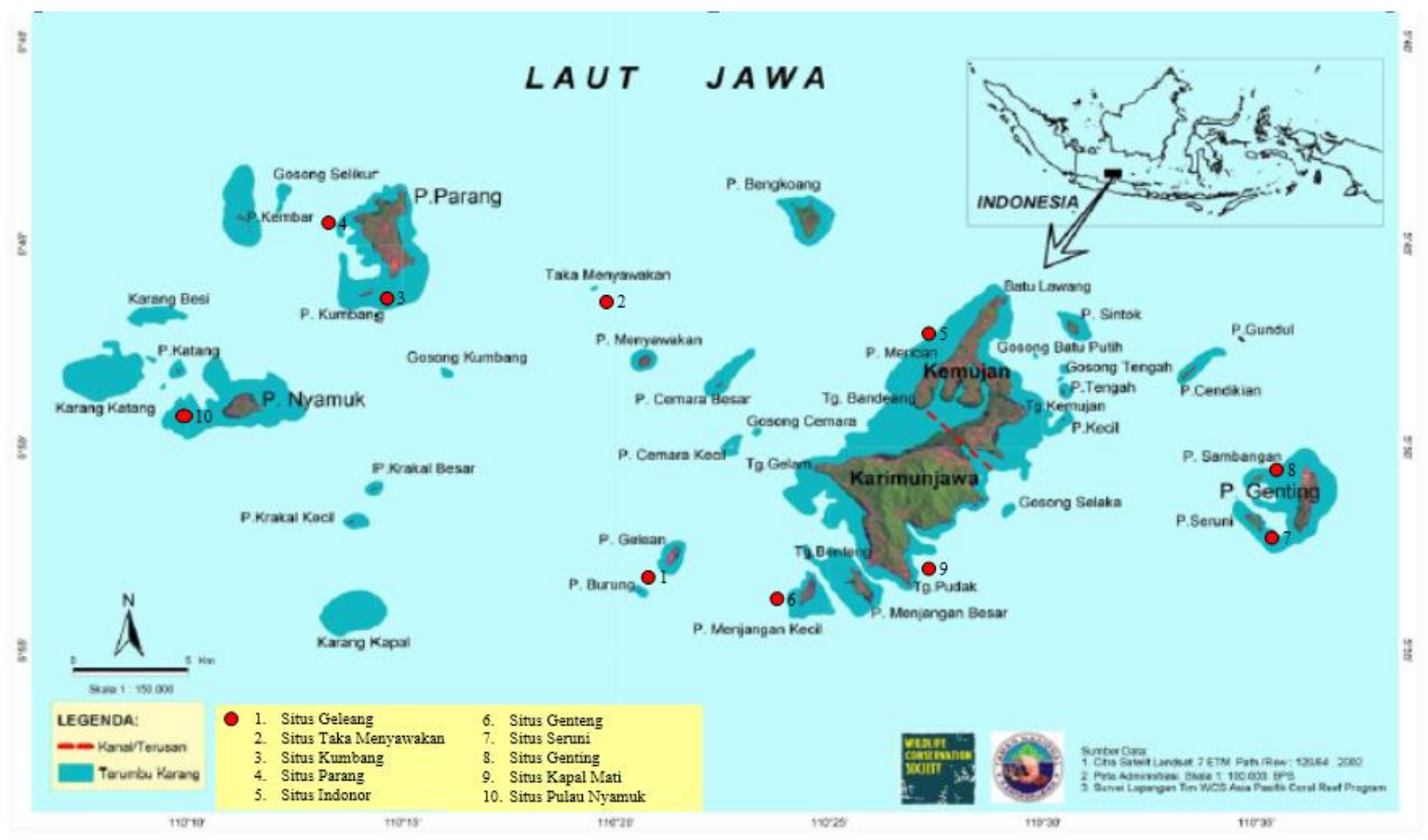

Fig. 2. Map of Sites in Karimunjawa Archipelago

Map Source: World Conservation Society (with the addition of UCH sites)

\section{SignifiCANCE OF Underwater CUltural Heritage}

Sites in Karimunjawa are underwater cultural resources of Indonesia. It comprises of shipwrecks and its cargo. Although some of the shipwrecks are not 50 years old, but it has the potential as a cultural resource. Therefore, we need to determine its value of the sites. It is to ensure the preservation of these resources can be beneficial not only for archaeology or culture but for the general public.

Significance is a quality and originality of a cultural heritage that can be measured and be seen directly. According to the Australia ICOMOS Charter for the Conservation of Places of Cultural Significance (The Burra Charter) April 1988, Cultural Significance is defined as estimation of aesthetic, historical, science, or social significance for the past, present, and future generation.

Value in a site is an aspect tht gives legality and justification in the process of preservation and utilization of the site (Feilden dan Jokilehto, 1993: 17). Value system is broadly explained by many scholars. Bernard M. Feilden dan Jukka Jokilehto (1993: 17-20) stated that archaeological object contains two value, that is cultural value and socio-economy value with each gives positive and negative impact on the object. Cultural value can be seen as an intrinsic value, which refers to the aspect of shape and material, technology, design, and architecture, and also space setting and historical context of the site. Type of value that include in a cultural value are:

- Identity value, this value is connected with the emotional attachment of people to the object. Element that determine identity value are age, tradition, legends, sentiment, spiritual, religion, symbolical, ideological, patriotic, and nationality. If this value is very high it sometimes causes the treatment to disregard the preservation of the object, whereas if the value is low will trigger the people ignorance for the destruction and vandalism.

- Technology and artistic value, is a value referring to the importance of object to the science and historical framing seen by the element of technique, structural, function, and manufacturing. Thus value commonly appears through research that shows object classification and its development relevance of past, present and other period.

- Uniqueness value, this value is connected with element of similarity of type, style, founder, and region. This value is also connected with the other two values.

Underwater heritage is an important resource from nondocumentary evidence of social and economic history. Besides distributing food and goods, boat and ship help spread idea and invention from one place to another, while sunken prehistoric site provide information about our ancestors. The development of shipping as mean of transportation often describe as 'equal to the human evolution in controlling fire'. This development shaped 'the advance' of technology from a pre-industrial society from Mesolithic period to the next. Boat and ship is a 'micro cosmos' from the technology that shape it and the people that use it. Sunken ship often called as 'time capsules', because time stop for that ship immediately after it sunk and become a 'closed remains'. 
Every sunken ship gives archaeologist evidences about:

1) The original ship and its equipment: the hull shows the architecture and ship building.

2) Parts of the ship such as propulsion, anchor, sail, steering wheel.

3) Main purpose of the ship: cargo in a trading ship, ammunition in a warship, special equipment such as net in a fishing ship.

4) The life of the crew on board: tools, weapon, and also personal items of the passenger and the ship's crew. Ornamentation in the ship can also give important information about the daily lives of the past culture.

Research on sites of Karimunjawa Archipelago is still very little. These sites have the potential for the development of science for archaeology or other discipline.

From the perspective of archaeology, sunken ship in Karimunjawa can describe the trading history of that region. Furthermore, it can explain the cargo that was carried by the ship. From a marine science perspective it can give an overview of ship shape and type of the region.

Sites in Karimunjawa Archipelago can also be an educational area for the people that tell about the cultural and natural history. The people can know the importance of protecting the cultural resource so that can last for future generation.

The people can know the historical connection inter-island in Indonesia and with other foreigner based on ships, cargo, the passenger's and crew's lives, shipping line and the event of the shipwreck in that area. Furthermore, this sites cannot be seen separated from sites on the land, because of its inter connection with Java Island.

In an industrial field, shipwreck, like the S.S. Indonor in Karimunjawa can be a place for education in shipping technique. From the shipwreck can be learn about how steam ship work that was made in England. Furthermore, some shipwreck in Karimunjawa which are in shallow water such as Kumbang or Menyawakan site can be a place for training of underwater archaeology. Nowadays there are several locations that become a training ground for elementary diving or SCUBA Diving.

The preservation of underwater cultural heritage can have political value, especially for Indonesia as a maritime nation. By preserving underwater cultural heritage, it can also support the government program in making Indonesia as a maritime axis.

This is delivered by the President of Republic of Indonesia, Joko Widodo in East Asia Summit in Nay Pyi Taw, Myanmar, on 13th November 2014. The development forms that will undertake are rebuilding the maritime culture of Indonesia and protect as well as manage marine resources. The richness of maritime would be utilized as big as possible for people's interest.

Therefore through UCH preservation, Indonesian people protect their maritime cultural heritage, develop the maritime cultural heritage, and show to the world that Indonesia is a maritime country, which rooted since the past.

\section{CONCLUSION}

UCH left from the past and discover in present time, contain substantial information value. In Karimunjawa waters, there are remains of sunken shipwreck found since Karimunjawa was seafaring route and it had some dangerous track due to much corals cause shallowing the water depth. Those shipwrecks was from different era, therefore by analyzing them we can understand the evolution of shipping technology through the age. Besides that, based on the cargo, we can get information about trading commodities carried by ships in the past, therefore we can understand about cultural contact among Java Island, Karimunjawa, and other areas in Nusantara, as well as overseas.

This kind of information that should be developing and packed in order to published to Indonesia people. Therefore it could increase the public awareness to take part in protecting and preserving $\mathrm{UCH}$ in Karimunjawa and furthermore in Indonesian waters.

There are many ways to preserve UCH sites and publish its information and knowledge. One of them is through museum, because museum has two functions, as a preservation and communication institution. Karimunjawa sites are very potential to become in-situ underwater museum. But it needs a proper management, which is structured by an institution or a legal body. And its information needs to be organizes very well. Of course there are a lot of thing to be prepared such as funding, organization, human resource, and information.

UCH management in the shape of underwater museum would have some advantages, as well as some challenges. $\mathrm{UCH}$ sites utilization as an underwater museum in Karimunjawa would be very potential in some areas. Those potential are:

\section{A. UCH Preservation}

With its strategic location, Karimunjawa was used as a transit harbor in Java Sea. It was a busy harbor visited by many foreign and local ships. A considerable UCH in Karimunjawa describes Indonesia as a maritime nation who is capable of roaming the sea and have relation with foreign nation. By utilizing the sites as a museum, we could maintain the preservation of the wreck site and its environment to last for the future.

\section{B. Education and science}

Sites in Karimunjawa could be a place for education and science about history, culture, and nature. People can learn about the importance of the sites and its environment from many points of view.

\section{Political}

The preservation of $\mathrm{UCH}$ can support the Government program to make Indonesia as a maritime axis with the concept of Nawa Cita from the President of Indonesia, Joko Widodo.

\section{Economical}

Economically, tourism in Karimunjawa is very high. Wreck diving could be the main attraction for sport tourist. Other than that, indirect economical benefit from tourist can lift the standard of living of the Karimunjawa people. 


\section{E. Information Dissemination}

Information about the importance of Karimunjawa site and its history needs to be developed and packed to be publicized to the people. Therefore, it can increase the people awareness to protect and preserve UCH in Karimunjawa and furthermore in other region in Indonesia.

On the other hand, the potential of utilizing $\mathrm{UCH}$ as a museum in Karimunjawa would face some challenges since it is a new concept in Indonesia and has not been implemented in any other sites in Indonesia. Those challenges are:

1) Lack of information about UCH sites in Karimunjawa, so it needs more research to dig out the data and information behind the sites

2) Lack of knowledge about UCH management among the local government, while the UCH management in local area is the responsibility of local government

3) Vandalism through human activity and natural process would cause some changes or degradation of the UCH sites

4) Lack of access to Karimunjawa, because of the transportation from Java (Jepara and Semarang) is very limited, so it would cause some difficulties for tourist visiting Karimunjawa

5) Need a big amount of funding and special skill of human resources to manage $U C H$ sites as a museum because it is a very special major.

Degradation of UCH sites in Karimunjawa would continue to increase as the time goes. It needs our awareness to protect the sites. The concept of utilizing UCH sites as an underwater museum could be one of consideration of preserving sites and learning method. Therefore, archaeological sites preservation through the museum is very important as an identity of
Indonesian people as a maritime nation and its existence is necessary maintained for the next generation.

\section{ACKNOWLEDGMENT}

The preferred spelling of the word "acknowledgment" in America is without an "e" after the "g." Avoid the stilted expression "one of us (R. B. G.) thanks ...". Instead, try "R. B. G. thanks...". Put sponsor acknowledgments in the unnumbered footnote on the first page.

\section{REFERENCES}

[1] Anwar, Rosihan (2004). Sejarah Kecil "Petit Histoire" Indonesia. Jakarta: Kompas.

[2] Berg, J. van (1992)., Het Hoge Huis aan de Javazee. 's Gravenhage: Bzztoh.

[3] Feilden, B. M. and Jukilehto, J. (1993) Management Guidelines for World Cultural Heritage Sites. Roma: ICCROM.

[4] Gonggrijp, G.L. (1915). De Karimoen Djawa Eilanden, Tidjschrift Voor Het Binnenladsch Bestuur, Vierde Jaargang, Eerste Halfjaar. Batavia: Lange Co.

[5] Indonesian Law Number 112010 aboy the Cultural Property.

[6] Koestoro, L.P. (1997). Karimunjawa dan Sisa Benda Budaya Masyarakat Pulau-pulau di Perairan Utara Jawa.Berkala Arkeologi, Tahun XVII No 2 November 1997. Yogyakarta: Balai Arkeologi. 37-51.

[7] Noerwidi, Sofwan (2008). Jejak Kejayaan Bahari Karimunjawa in http://arkeologika.files.word press.com/2008/01/sofwan_bahari.pdf, 2008 .

[8] Sulistiyono, S.T. (2008). Dinamika Kemaritiman dan Integrasi Negara Nasional di Indonesia. Setengah Abad Deklarasi Djuanda 1957 - 2007. Jakarta: Departemen Kebudayaan dan Pariwisata Direktorat Jenderal Sejarah dan Purbakala Direktorat Geografi Sejarah. 40 - 71.

[9] Sutikno. (2008) "Kewilayahan Indonesi Dahulu dan Sekarang" dalam Setengah Abad Deklarasi Djuanda 1957 - 2007. Jakarta: Departemen Kebudayaan dan Pariwisata Direktorat Jenderal Sejarah dan Purbakala Direktorat Geografi Sejarah. 22 - 39.

[10] UNESCO Convention On the Protection of The Underwater Cultural Heritage 